\title{
In Patients with ST-Elevated Myocardial Infarction The Relationship Between Complications Developed and Age
}

\author{
ST-Elevasyonlu Miyokard Enfarktüs Olgularında Gelişen Komplikasyonların \\ Yaş ile iliş̧kisi
}

\author{
Nursel Kocamaz ${ }^{1 \oplus}$, Gulcin Sahingoz Erdal ${ }^{1 \oplus}$, Pinar Kasapoglu² ${ }^{2}$, Nilgun Isiksacan ${ }^{2 \oplus}$ \\ ${ }^{1}$ Health Science University, Bakirkoy Dr Sadi Konuk Training and Research Hospital, Department of Internal Medicine, Istanbul, Turkey \\ ${ }^{2}$ Health Science University, Bakirkoy Dr Sadi Konuk Training and Research Hospital, Department of Biochemistry Istanbul, Turkey
}

Received: 22 December 2019 / Accepted: 04 April 2020 / Publication date: 26 June 2020

Cite as: Kocamaz N, Sahingoz Erdal G, Kasapoglu P, Isiksacan N. in Patients with ST-elevated myocardial infarction the relationship between complications developed and age. Med J Bakirkoy 2020;16(2):138-42.

\begin{abstract}
Objective: Coronary artery diseases (CADs) are the most common causes of death worldwide. Every year more than 7 million people die of CAD which accounts for $12.8 \%$ of all-cause deaths. Generally, while a part of the patients recovered without any complication during the 3-4 week course of acute myocardial infarction, various complications may occur in the majority of patients.

Method: In our study, we compared the relationship between the age and the early complications of the 488 ST- elevated acute myocardial infarction patients in the coronary intensive care unit in Hamidiye Şişli Etfal Hospital Coronary Intensive Care Unit between January 1988 and June 1991.

Conclusion: In our study, although there was no significant difference in terms of myocardial infarction complications between the two groups under 60 years old and above, heart failure, cardiogenic shock, premature death and cerebrovascular diseases were more frequent in the group over 60 years of age. However, no complication was observed in a total of 129 patients (26.4\%). It is generally found that young patients with myocardial infarction have low mortality and better prognosis; which may be related to their better health status or smaller area of myocardial infarction, it should also be taken into consideration that collateral vessels may develop in time. In the elderly, so they can overcome the infarction more easily which increases the possibility of surviving their post-infarction life.
\end{abstract}

Keywords: acute myocardial infarction, ST-elevation, age

Öz

Amaç: Koroner arter hastalıkları (KAH) tüm dünyada ölümün en sık nedenidir. Her yıl 7 milyondan fazla kişi KAH nedeniyle ölmektedir ve tüm ölümlerin \%12,8'sini oluşturmaktadır. Genel olarak akut miyokard inlarktüsünün 3-4 haftalık seyrinde hastaların bir bölümü komplikasyonsuz olarak iyileşirken hastaların büyük çoğunluğunda, değişik önemde çeşitli komplikasyonlar ortaya çıkabilir.

Yöntem: Çalışmamızda, Hamidiye Şişli Etfal Hastanesi Koroner Yoğun Bakım Ünitesinde 1988 Ocak-1991 Haziran ayları arasında koroner yoğun bakım ünitesinde takip ettiğimiz 488 ST elevasyonlu akut miyokard infarktüsü hastasında gelişen erken komplikasyonların yaş ile ilişkilerini karşılaştırdık.

Sonuç: Yaptığımız çalışmada 60 yaş altı ve üstü her iki grup arasında miyokard infarktüsü komplikasyonları yönünden genelde anlamIı fark olmamakla birlikte, kalp yetmezliği, kardiyojenik şok, erken ölüm, serebrovasküler hastalıklar 60 yaş üstü grupta daha sıktı. Bununla birlikte toplam 129 hastada (\% 26.4) hiç bir komplikasyon görülmedi. Çalışmalarda genellikle genç miyokard infarktüslülerin mortalitesinin düşük, prognozunun daha iyi bulunması genç hastaların sağlık durumu veya miyokard infarktüs alanının daha elverişli olmasına bağlı olabileceği düşünülse de, yaşılıarda zamanla kolleteral damarların gelişebileceği, infarktı daha kolay atlatabilecekleri ve infarkt sonrası yaşamlarını sürdürebilme olasılığını arttıracağı da göz önünde bulundurulmalıdır.

Anahtar kelimeler: akut miyokart enfarktüs, ST elevasyonu, yaş

Corresponding Author:

nurselkocamaz@hotmail.com
N. Kocamaz 0000-0003-3489-2329

G. Sahingoz Erdal 0000-0001-5815-5847

P. Kasapoglu 0000-0003-1703-2204

N. Isiksacan 0000-0002-0230-6500

(c) Telif hakkı Sağlık Bilimleri Üniversitesi Bakırköy Dr. Sadi Konuk Eğitim ve Araştırma Hastanesi'ne aittir. Logos Tıp Yayıncılık tarafindan yayınlanmaktadır. Bu dergide yayınlanan bütün makaleler Creative Commons Atff-GayriTicari 4.0 Uluslararası Lisansı ile lisanslanmıștır.

(c) Copyright Health Sciences University Bakırköy Sadi Konuk Training and Research Hospital. This journal published by Logos Medical Publishing. Licenced by Creative Commons Attribution-NonCommercial 4.0 International (CC BY-NC 4.0) 


\section{INTRODUCTION}

Coronary artery diseases (CADs) are the most common causes of death worldwide. More than 7 million people die every year due to CAD which accounts for $12.8 \%$ of all-cause deaths ${ }^{(1)}$.

Myocardial infarction (MI) is defined as myocardial cell death due to prolonged ischemia in pathology. Electrocardiography (ECG) and measurement of cardiac biomarkers are the current diagnostic cornerstones that complement the clinical assessment ${ }^{(2)}$. Clinical manifestations of ischemic heart disease are silent ischemia, stable angina pectoris, unstable angina, $\mathrm{MI}$, heart failure and sudden death ${ }^{(3)}$.

In Turkey, according to the data of the TEKHARF (Heart Disease and Risk Factors in Turkish Adults) study, it is estimated that approximately 2 million people have CAD, and annually 90-100 thousand new cases occur, and 130,000 people die due to $\operatorname{CAD}^{(4,5)}$.

Generally, in the 3-4 week course of acute myocardial infarction, some of the patients recover without compilications. But in the vast majority of patients, various complications of different significance may occur. Dysrhythmias (bradyarrhythmia, fascicular block, tachyarrhythmia, ventricular tachycardia, ventricular fibrillation), left ventricular failure, cardiogenic shock, myocardial rupture, ventricular aneurysm, left ventricular thrombus and arterial embolism, pulmonary embolism, pericardial effusion, pericarditis, Dressler syndrome, sudden death are some of these complications. The occurrence of these complications depends on the size of the infarction, its localization, age, gender, risk factors carried by the person, whetherthe patient has had an infarction before, and patient's timely transport to the hospital and coronary units ${ }^{(6)}$. In our study, in patients with ST-elevated acute myocardial infarction that we followed up in the coronary intensive care unit; we aimed to investigate the relationship between early complications and age.

\section{MATERIAL and METHOD}

Four hundred and eighty-eight patients who were hospitalized in the Hamidiye Şişli Etfal Hospital Coronary Intensive Care Unit with the diagnosis of ST -elevated myocardial infarction (STEMI) between
January 1988 and June 1991 were included in the study. In patients included in the study and diagnosed with STEMI; an anamnesis of ischemic chest pain lasting more than 20 minutes, newly emerged pathological Q wave changes, ST and T wave changes in ECG, and typically increasing and decreasing serum enzyme activities were elicited. Since all patients firstly applied to our emergency outpatient clinic of internal medicine, their first echocardiographic examinations (ECG) were performed there, and then repeated every day during their stay in the intensive care unit.

ECGs were taken at a rate of $25 / \mathrm{sec}$ and a total of 12 leads were examined including 3 standard, 3 unipolar extremity, and 6 precordial leads. Meanwhile, electrocardiographic traces and D2 and V1 derivations were recorded and examined for a long time to better recognize the rhythm disturbances. Complications as rhythm and conduction disorders were detected during continuous follow-up, and evaluated in line with changing and developing symptoms and signs. For this purpose, fever, arterial blood pressure, pulse rate, and heart rate were measured, and frequent physical examinations were performed.

Complete blood count, erythrocyte sedimentation rate, complete urinalysis, serum glutamic oxalacetic transaminase (SGOT), lactate dehydrogenase (LDH), creatine kinase (CK), CK-MB, blood sugar, creatinine, blood urea nitrogen, blood electrolytes were evaluated in each patient These tests were performed in biochemistry and bacteriology laboratory of our hospital. Meanwhile, SGOT, LDH, CK, CK-MB analyses were repeated every day in terms of progression of acute myocardial infarction. Echocardiographic and angiographic procedures were also performed in patients in case of need, and cranial imaging was also performed if necessary.

\section{RESULTS}

Four hundred and eighty-eight patients who applied to our clinic between 1988 and 1991 and followed up in the Coronary Intensive Care Unit with the diagnosis of ST -Elevated Acute Myocardial Infarction; were divided into two age groups as those aged $\leq 60$ (Group 1; $n=254)$ ), and $>60$ years (Group 2: $n=234$ )). Complications of myocardial infarction in the coronary 
Table 1. Comparison of complications in both groups.

\begin{tabular}{|c|c|c|c|c|}
\hline Complications & $\begin{array}{c}\text { Group } 1 \\
\mathrm{n}: 255\end{array}$ & $\begin{array}{c}\text { Group } 2 \\
\mathrm{n}: 234\end{array}$ & Total & $\mathbf{p}$ \\
\hline Dysrhythmia & $104(40.9 \%)$ & $73(31.2 \%)$ & 177 (36.3\%) & $<0.3$ \\
\hline Heart failure & 25 (9.8\%) & $62(26.5 \%)$ & $87(17.8 \%)$ & $<0.001$ \\
\hline Cardiogenic shock & $14(5.5 \%)$ & $26(1.1 \%)$ & $40(8.2 \%)$ & $<0.05$ \\
\hline Pericarditis & $13(5.1 \%)$ & $5(2.1 \%)$ & $18(3.7 \%)$ & $<0.1$ \\
\hline Ventricular fibrillation & 12 (4.7\%) & $21(9 \%)$ & $33(6.8 \%)$ & $<0.1$ \\
\hline Sudden death & $1(0.4 \%)$ & $3(1.3 \%)$ & $4(0.8 \%)$ & $<0.3$ \\
\hline Uncomplicated & $85(33.4 \%)$ & $44(18.8 \%)$ & $129(26.4 \%)$ & $<0.001$ \\
\hline
\end{tabular}

intensive care unit in Groups 1, and 2 were compared.

Three hundred and seventy-three (76.4\%) patients were men and 118 (24.1\%) of them were women. The ages of the patients ranged between 21, and 96 years, (mean: 57.38 years), the ages of women ranged between 35, and 87 years (mean: 63.87 years). Complications evaluated in both groups were dysrhythmias, congestive heart failure (CHF), severe rhythm disorder (ventricular tachycardia and fibrillation), pericarditis, sudden death, and cardiogenic shock. These complications were monitored while patients were hospitalized in the coronary intensive care unit. However, no complications were observed in 129 patients (26.4\%) (Table 1 ).

There was no significant difference in terms of ventricular fibrillation in both groups $(p<0.1)$. However, 8 of 12 patients aged 60 and under responded to defibrillation, but 4 patients died (33.3\%). In Group 2 16 patients $(76.1 \%)$ died. Ventricular fibrillation was seen in the group aged over 60 , and led to more mortal consequences.

Cerebral hemorrhage, embolism and ischemic attacks were evaluated as cerebrovascular disease (CVD). CVD was observed in a total of 12 patients (2.4\%), 2 of them were under the age of 60 and 10 were over the age of 60 . There was a significant difference between the two groups $(p<0.01)$.

Seventy-six of 488 patients in the study were lost while being followed up in the coronary intensive care unit, and $75 \%$ of deaths occurred in the first day. Twenty-three $(9.05 \%)$ patients aged $\leq 60$ years, and 53 patients over 60 years of age (22.6\%) exited These two mortality rates were found to be highly statistically significant $(p<0.001)$ (Table 2 ).
Table 2. Mortality of patients followed in coronary intensive care unit.

\begin{tabular}{lcccc}
\hline & Group 1 & Group 2 & Total & p \\
\hline Surviving & 254 & 234 & 488 & $<0.001$ \\
Deceased & $23(9.05 \%)$ & $53(22.6 \%)$ & $76(45.5 \%)$ & \\
\hline
\end{tabular}

\section{DISCUSSION}

We investigated the distribution of the complications developed in 488 patients diagnosed with ST-elevated acute myocardial infarction in the coronary intensive care unit of our hospital between 1988 and 1991, by age groups and compared our results with the literature. The frequency of rhythm and conduction disorders without ventricular fibrillation was largely in line with studies on this subject (7-9). In our study, ventricular fibrillation developed in a total of 33 patients, and there was no significant difference in terms of frequency of ventricular fibrillation between the two age groups. This result was compatible with the studies in the literature ${ }^{(7-9)}$.

A total of 87 patients had various levels of heart failure, and a statistically significant difference was found in terms of heart failure in the group aged over 60 years $(p<0.001)$. Some studies published similar results, ${ }^{(10-12)}$; while in some other studies any significant difference could not be detected in terms of heart failure among age groups ${ }^{(13)}$.

Cardiogenic shock developed in 40 of the patients we followed and these patients were more commonly over the age of 60 . Some studies in the literature supported our data ${ }^{(10-12)}$, while others revealed different results $(8,9,14)$. Early deaths in our coronary intensive care patients were found to be significantly more common over 60 years of age, and this result is com- 
patible with similar studies in the literature ${ }^{(12,13)}$

Eighteen of the patients we followed developed pericarditis, and although not statistically significant, pericarditis were more frequently seen under the age of 60 . Findings of Farrell et al. and also James et al. were compatible with the findings in our study $(12,13)$.

In our study, although there is no significant difference in terms of complications of myocardial infarction between both groups under and over 60 years of age; heart failure, cardiogenic shock, early death, cerebrovascular diseases were more common in the group over 60 years of age.

Although the infarct size was smaller in the elderly compared to the younger ones, left ventricular ejection fraction was lower, and congestive heart failure and cardiogenic shock developed more frequently. Thus, acute myocardial infarction became less lethal in young patients than in the elderly. However, tolerance to heart failure, arrhythmia and hypotension was significantly lower in the elderly. Opinions stating that the significant difference in mortality between the two groups can be explained by the more frequently seen multisystem diseases in elderly patients are generally supported.

Other predisposing causes to heart failure in the elderly are cardiovascular diseases such as age-related left ventricular hypertrophy, decreased ventricular compliance, and concomitant hypertension.

Mortality and morbidity rates in our elderly patients were similar to mortality and morbidity rates in other studies. All over the world, the incidence of myocardial infarction increases with age. Although mortality and morbidity rates are higher in the elderly after acute myocardial infarction, specific factors responsible for higher complication rates have not been clearly identified ${ }^{(12)}$.

It has been generally reported that young patients with myocardial infarction have low mortality rates, and better prognosis; may be due to their better health status or smaller area infarct area. In the elderly it should also be taken into consideration that collateral vessels may develop in time, so they can overcome the infarction more easily which increases their post-infarction survival rates.

Ethics Committee Approval: Bakırköy Dr. Approval was obtained from the Sadi Konuk Training and Research Hospital Clinical Research Ethics Committee (218/33, 13.09.2018).

Conflict of interests: There is no conflict of interest. Funding: There is no funding.

Informed Consent: Informed consent of the patients was obtained.

\section{REFERENCES}

1. Steg PG, James SK, Atar D, et al. ESC Guidelines for the management of acute myocardial infarction in patients presenting with ST-segment elevation. Eur Heart J. 2012;33(20):2569619.

https://doi.org/10.1093/eurheartj/ehs215

2. Alpert JS, Thygesen K. A new global definition of myocardial infarction for the 21st century. Pol Arch Med Wewn. 2007;117(11-12):485-6.

PMID: 18363245 https://doi.org/10.20452/pamw.232

3. Bassand JP, Hamm CW, Ardissino D, Boersma E, Budaj A, Fernández-Avilés $F$, et al. ST segment yükselmesi olmayan akut koroner sendromların tanı ve tedavi kılavuzu. Eur Heart J. 2007;28(13):1598-660. https://doi.org/10.1093/eurheartj/ehm161

4. Enar R. Temel kardiyoloji semiyoloji ve kardiyovasküler hastalıklar. İstanbul: Nobel Tıp Kitabevleri; 2007. p. 557-9.

5. Onat A, Uğur M, Çiçek G, et al. TEKHARF 2009 taraması: Kırsal kesim ve kentlerde benzer kardiyovasküler ölüm riski. Türk Kardiyol Dern Arş. 2010;38(3):159-63.

6. Amsterdam EA, Wenger NK, Brindis RG, Casey DE Jr, Ganiats TG, Holmes DR Jr, et al. 2014 AHA/ACC Guideline for the Management of Patients with Non-ST-Elevation Acute Coronary Syndromes: a report of the American College of Cardiology/American Heart Association Task Force on Practice Guidelines. J Am Coll Cardiol. 2014;64(24):e139-e228. Erratum in: J Am Coll Cardiol. 2014;64(24):2713-4. Dosage error in article text. PMID: 25260718. https://doi.org/10.1016/j.jacc.2014.09.017

7. Davia JE, Hallal FJ, Cheitlin MD, Gregoratos G, McCarty R, Foote W. Coronary artery disease in young patients: arteriographic and clinical review of 40 cases aged 35 and under. Am Heart J. 1974;87(6):689-96. PMID: 4828802. https://doi.org/10.1016/0002-8703(74)90412-8

8. Dolder MA, Oliver MF. Myocardial infarction in young men. Study of risk factors in nine countries. $\mathrm{Br}$ Heart $\mathrm{J}$. 1975;37(5):493-503. PMID: 1137658; PMCID: PMC482827. https://doi.org/10.1136/hrt.37.5.493

9. Bergstrand R, Vedin A, Wilhelmsson C, Wallin J, Wedel H, Wilhelmsen L. Myocardial infarction among men below age 40. $\mathrm{Br}$ Heart J. 1978;40(7):783-8. PMID: 687475; PMCID: PMC483484. https://doi.org/10.1136/hrt.40.7.783

10. Harris R, Piracha AR. Acute myocardial infarction in the aged: prognosis and management. J Am Geriatr Soc. 1970;18(11): 893-904. PMID: 5471846 https://doi.org/10.1111/j.1532-5415.1970.tb02841.x

11. Yang XS, Nillems JL, DeGest H.Acute myocardial infarction in the aged: prognosis and manegment. J Am Geriatr Soc18:893- 
4,1970.

https://doi.org/10.1111/j.1532-5415.1970.tb02841.x

12. Tofler GH, Muller JE, Stone PH, et al. Factors leading to shorter survival after acute myocardial infarction in patients ages 65 to 75 years compared with younger patients. Am J Cardiol. 1988;62(13):860-7.

PMID: 3177233

https://doi.org/10.1016/0002-9149(88)90882-X
13. Uhl GS, Farrell PW. Myocardial infarction in young adults: risk factors and natural history. Am Heart J. 1983;105(4):548-53. PMID: 6837409.

https://doi.org/10.1016/0002-8703(83)90476-3

14. Walker WJ, Gregoratos G. Myocardial infarction in young men. Am J Cardiol. 1967;19(3):339-43.

PMID: 6020303.

https://doi.org/10.1016/0002-9149(67)90445-6 